\title{
sciendo SELECTED ASPECTS OF DEVELOPMENT OF HUMAN CAPITAL IN INDUSTRIAL ENTERPRISES
} doi:10.2478/mape-2018-0064

Date of submission of the article to the Editor: 03/2018

Date of acceptance of the article by the Editor: 07/2018

MAPE 2018, volume 1, issue 1, pp. 507-513

\author{
Dr Eng. Marzena Ogórek \\ Dr Eng. Dominika Strycharska \\ Czestochowa University of Technology, Poland
}

\begin{abstract}
This paper presents the results of research, conducted using a questionnaire form, in dynamically developing industrial enterprises located in the economic zones of southern Poland. The results of these studies were referred to research carried out in public utility entities located in the same geographical area. These studies concerned, among others, the development of human and intellectual capital, which is why analysis was carried out on the following issues: the level of cooperation between colleagues, the level of exchange of information and experience among colleagues, the manager understands and facilitates the flow of information among colleagues, the degree of computerization in the workplace and the implementation of solutions in the company aimed at preserving the acquired knowledge and experience.
\end{abstract}

Keywords: human resources management, human capital, intellectual capital,

\section{INTRODUCTION}

The transformations taking place in the modern world pose particular challenges to enterprises, thus leading to a change in the factors affecting market success and the ensuing economic result. Research conducted by many scientists aimed at identifying factors determining the competitiveness of enterprises already demonstrated several decades ago that employees, along with their knowledge and personality traits, constitute a strategic resource of an enterprise, which has an impact on its functioning and the construction of its value. Currently, it is assumed that the employee in every organization is primarily its huge capital, and is not just the workforce (Prusak, 2013; Huselid et al., 1997).

Good management of human resources and effective use of the potential inherent in them can transform them into human capital, or the most valuable resource of the company. The strategy of transforming human resources into company capital takes various forms of longterm decisions, focused on: adjusting employment to the changing environmental conditions; the impact on the environment; organizing expert groups around staff cells; rewards for effective work, as well as shaping the internal labor market of the company (Król and Ludwiczyński, 2006).

\section{HUMAN CAPITAL, AND INTELLECTUAL CAPITAL}

In recent years, the concept of "human capital management" has appeared more often in place of or beside the term "human resources management", employees are also referred to as capital, not just a resource (Wyrzykowska, 2013).

By definition, intellectual capital is a non-material asset with a complex structure that affects family life, the functioning of companies, societies and countries. Its essential components are: human capital, structural capital, client capital (Pocztowski, 2001; Imamoglu et al., 2017).

A review of the literature on the subject allows us to state that intellectual capital is a wealth based on knowledge. It is the sum of many intangible assets that shape the market value of an enterprise and is often referred to as the capital of knowledge or intellectual matter (Center 
of Consulting and Personnel Development, 2002). This capital is the sum of hidden assets not included in financial statements, including what is in the heads of employees, as well as what remains after they leave for home. Human capital is intellectual material that has been used to create valuable assets (Kasiewicz et al., 2006).

Human capital is the most important component of intellectual capital and is recognized in the literature in three perspectives (Skrzypek, 1999):

- economic theory of transaction costs - the activities of enterprises should be focused on selecting employees with a satisfactory level of competence and capable of implementing strategic goals;

- the theory of human capital - it refers to the level of outlays on investments in human capital, which is determined on the basis of knowledge, skills and experience of employees;

- personal paradigm - research on the competitive advantage, which can be obtained by using appropriately selected and deployed staff in the organizational structure.

The appreciation of human capital is the result of specific conditions in which modern enterprises function. Human capital analysts point to significant differences between the old and new reality. Theories of the old reality are characterized by the statement that people need enterprises whose source of competitive advantage is material and financial capital, and employees are loyal and value the stability of employment. However, the new reality is based on the message that enterprises need people, and intellectual capital decides about the competitive advantage, employees are mobile, and their relationship with the company is not long-term (Michaels et al., 2001).

\section{CHARACTERISTICS OF THE RESEARCH METHOD AND ANALYTICAL TOOL}

A survey was conducted in a dynamically developing industrial enterprise and in a public utility entity.

The survey was conducted using a questionnaire that the employees completed and then returned to the authors. In order to check the correctness of the tool and verify the knowledge of the respondents regarding the subject matter, a pilot study was carried out, which gave an image of the studied environment in its main outlines. The size of the sample was determined on the basis of consultations on the expected accuracy and representativeness of the assessments, and it amounted to 200. As a result of the survey, 191 questionnaires were obtained. The respondents answered 28 closed questions. The employed questionnaire was anonymous. The questions concerned two synthetic categories: the study of selected areas of human resources management and the development of human and intellectual capital.

In the questions, a five-point scale of assessment was used:

1. I strongly disagree;

2. I rather disagree;

3. I have no opinion;

4. I rather agree;

5. I definitely agree.

\section{ANALYSIS OF RESEARCH RESULTS}

4.1. The institution in which I am employed takes actions aimed at increasing the level of cooperation among colleagues

Figure 1 presents the answers to question 1 . In both the analyzed entities the distribution of responses is similar, i.e. it is mostly divided between assessments at levels 2, 3 and 4 . In the industrial enterprise, the highest percentage is negative responses of approx. $40 \%$ (at levels 1 and 2), this may mean that there are irregularities in this area, which is why this aspect requires additional analysis. On the other hand, in the public utility entity, the most positive answers (at the level of 4 and 5) constitute the most, approximately $40 \%$. The success of each enterprise depends on effective communication and cooperation of employees, therefore 
decision-makers should undertake activities aimed at increasing efficiency and avoiding conflicts among employees. Communication at the appropriate level allows one to establish professional cooperation and affects the smooth functioning of the team of employees, thanks to which the company can effectively achieve its goals and develop.

The data presented in Figure 2 concern the distribution of answers to question 1 in relation to the age of the employees. In the industrial enterprise in the age ranges: up to 25 years, from 26 to 30 and from 30 to 40 years, the majority of employees negatively evaluated the analysed issue (responses at levels 3 and 2). However, in the age group above 50 years, the majority of respondents positively assessed the phenomenon studied (at levels 4 and 3 ). In the public utility group, the respondents from the age groups up to 25 years, from 26 to 30 and from 40 to 50 years rated well the actions taken by the management in order to increase the level of cooperation among employees (the majority of answers at levels 3 and 4). The opposite situation takes place in the age range from 30 to 40 years, these employees mostly evaluate these activities negatively (responses at levels 3 and 2).

Research conducted using the chi-square independence test, at the significance level of $\alpha=$ 0.01 , allowed us to find a correlation between the assessment of actions undertaken to increase the level of cooperation among colleagues and the age of employees in both the industrial enterprise and the public utility entity. The values of the Pearson coefficient were 0.41 and 0.45 respectively, which allows us to find a correlation between these variables.
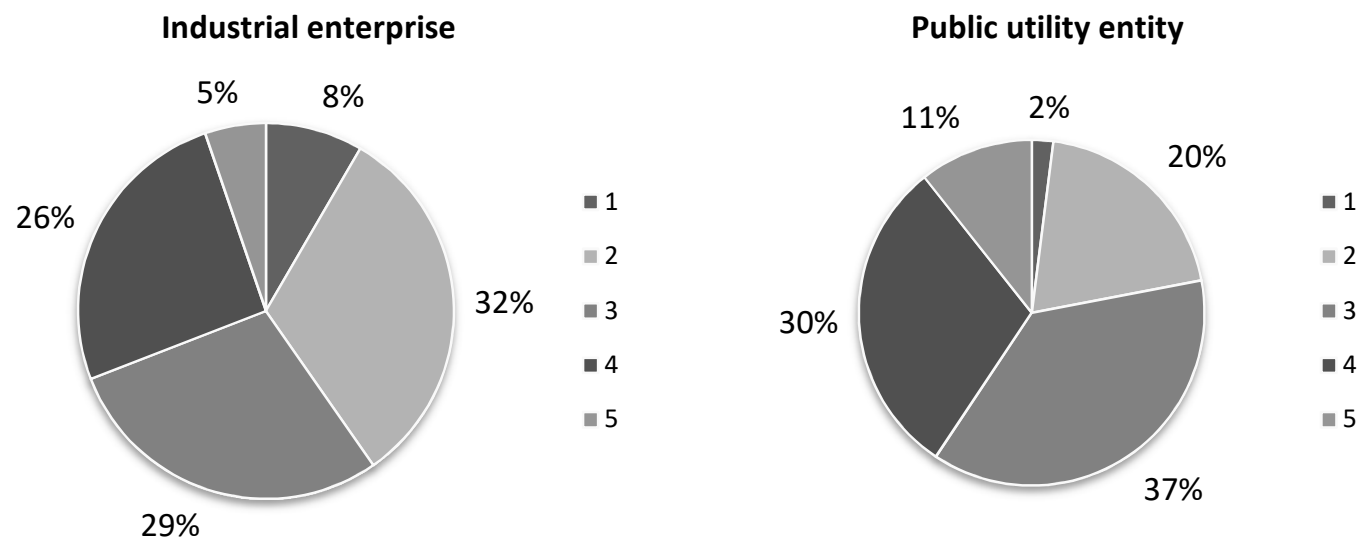

Fig. 1. Distribution of answers to question No. 1.

Designations: 1 - I strongly disagree, 2 - I rather disagree, 3 - I have no opinion, 4 - I rather agree, 5 - I definitely agree.
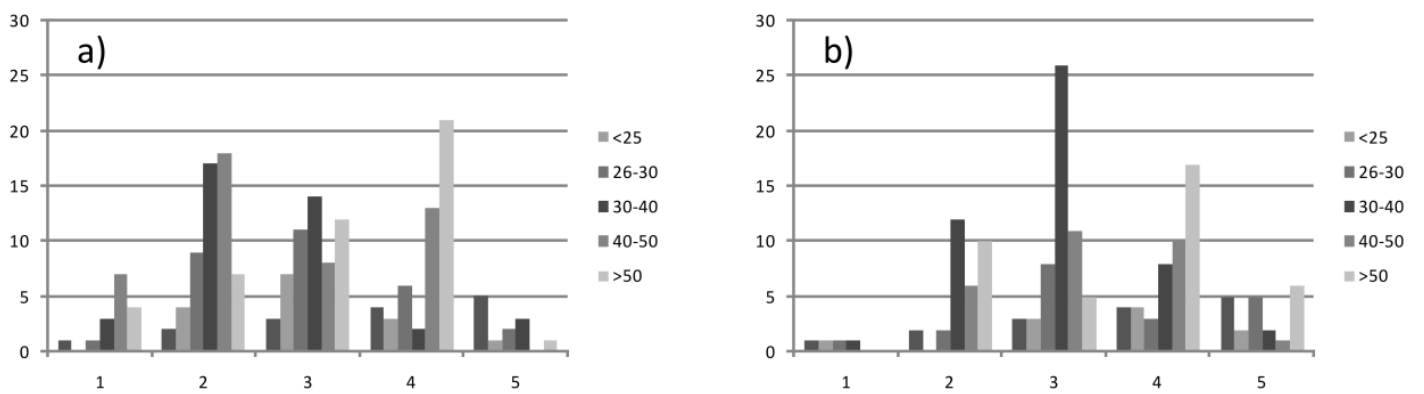

Fig. 2. Distribution of answers to question No. 1 according to the criterion of division: age.

Designations: 1 - I strongly disagree, 2 - I rather disagree, 3 - I have no opinion, 4 - I rather agree, 5 - I definitely agree; a) industrial enterprise, b) public utility entity. 


\subsection{In my workplace, we often exchange information and experiences with our} colleagues

Figure 3 presents data on the distribution of answers to question 2. The analysis allows us to conclude that in both analysed entities an advantage ratings of 4 and 5 was observed in this area, which may indicate the satisfaction of employees with the current level of exchange of information and experience. This is very important because it shows that the employees work well together and exchange obtained information and acquired experience.
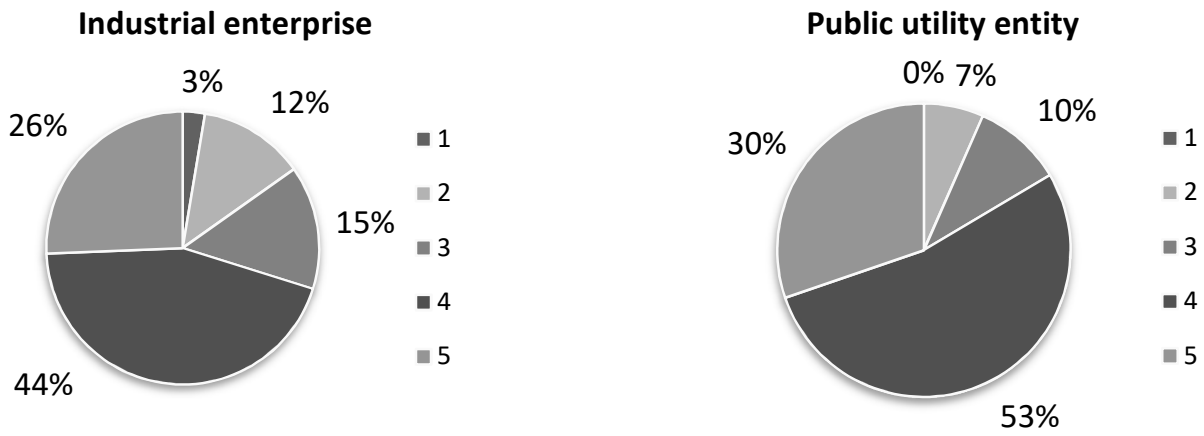

Fig. 3. Distribution of answers to question No. 2.

Designations: 1 - I strongly disagree, 2 - I rather disagree, 3 - I have no opinion, 4 - I rather agree, 5 - I definitely agree.

\subsection{My superior understands the need for information exchange among employees and takes steps to facilitate this process}

Figure 4 presents the distribution of answers to question 3 . The analysis allows us to conclude that in the industrial enterprise, extreme answers - at levels 1 and 5 (respectively: 14\% and $13 \%)$ constitute the smallest percentage, while the remaining responses were distributed among responses at 2, 3 and 4 . In the public utility entity the respondents gave at least $12 \%$ negative responses (at levels 1 and 2), while $66 \%$ of employees rated the analysed issue positively .

A very important element of cooperation in each team is the exchange of information among employees and the supervisor. Not only is the exchange of information easier to work in a team and implement tasks, but it also improves the working atmosphere, as there are no unnecessary short circuits.

Industrial enterprise

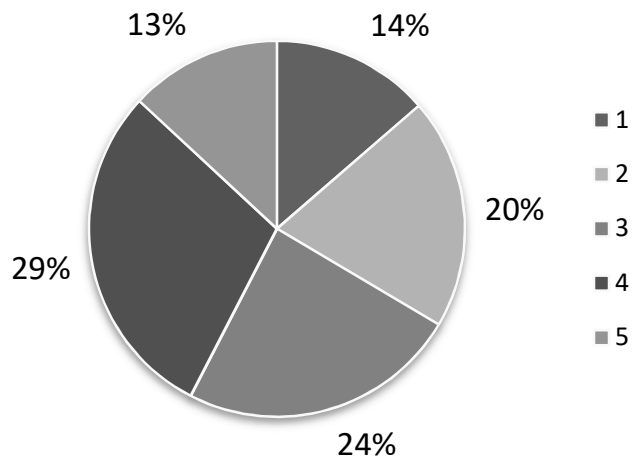

Public utility entity

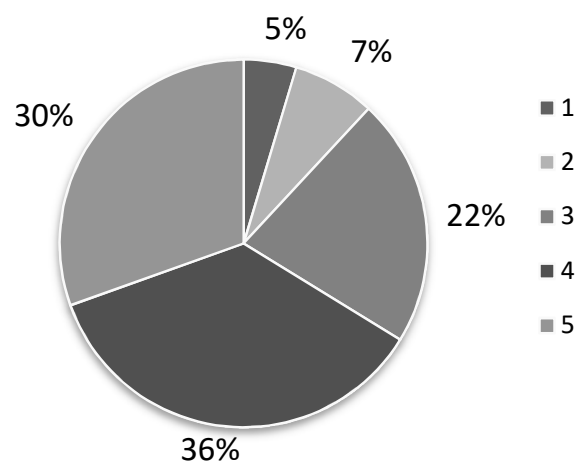

Fig. 4. Distribution of answers to question No. 3.

Designations: 1 - I strongly disagree, 2 - I rather disagree, 3 - I have no opinion, 4 - I rather agree,

5 - I definitely agree. 


\subsection{The degree of computerization of my workplace is sufficient from the point of view of efficiency}

Figure 5 presents the distribution of answers to question 4. It should be stated that in the industrial enterprise there is a large distribution of responses, the analyzed issue was negatively assessed by $30 \%$ of employees, positively $39 \%$ of employees and $31 \%$ gave the answer "I have no opinion". On the other hand, in the public utility entity more than $70 \%$ of the respondents gave answers at levels 4 and 5 .

It should be noted that the employees of the public utility entity very highly assessed the degree of computerization of their workplace and its impact on the effectiveness of their work. This may be related to many investments from the European Union addressed to public utility entities aimed at improving the IT infrastructure. In the industrial enterprise, 30\% of the employees rated the degree of computerization negatively, and $31 \%$ had no opinion on this matter - it may be due to the lack of necessary computer programs that would facilitate the work and affect its effectiveness.

Industrial enterprise

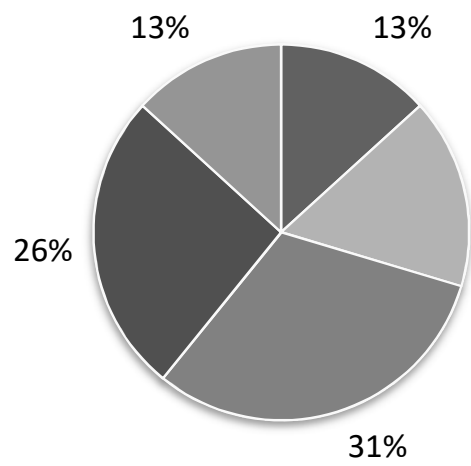

Publick utility entity

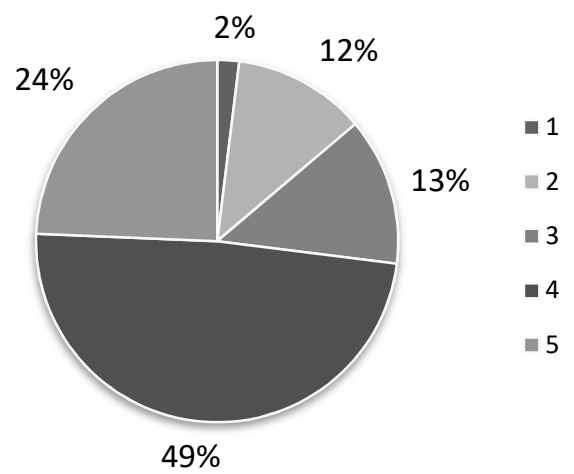

Fig. 5. Distribution of answers to question No. 4.

Designations: 1 - I strongly disagree, 2 - I rather disagree, 3 - I have no opinion, 4 - I rather agree, 5 - I definitely agree.

4.5. In the institution where I am employed, activities are carried out to preserve the knowledge and experience acquired

Figure 6 presents the distribution of answers to question 5. It should be stated that in both analysed entities the largest number of employees confirmed that such activities are carried out in their workplace (in the industrial enterprise $43 \%$, in the public utility entity $54 \%$ ).

Figure 7 presents data on the distribution of answers to question 5 in relation to the age of employees. It can be stated that in the industrial enterprise, the majority of employees in the internship range from 26 to 30 years, as well as those over 50 years old agree with the statement being analysed. In the public utility entities, the majority of employees from the age brackets up to 25 , from 26 to 30 , from 30 to 40 and over 50 years also agree with this statement.

Research conducted using the chi-square independence test, at the significance level of $\alpha=$ 0.01 , made it possible to find a relationship between the assessment of conducted activities aimed at preserving acquired knowledge and experience with the age of employees. The calculated value of the Pearson coefficient was 0.4 , which allows to conclude that there is a correlation in the industrial enterprise between the analysed variables. 

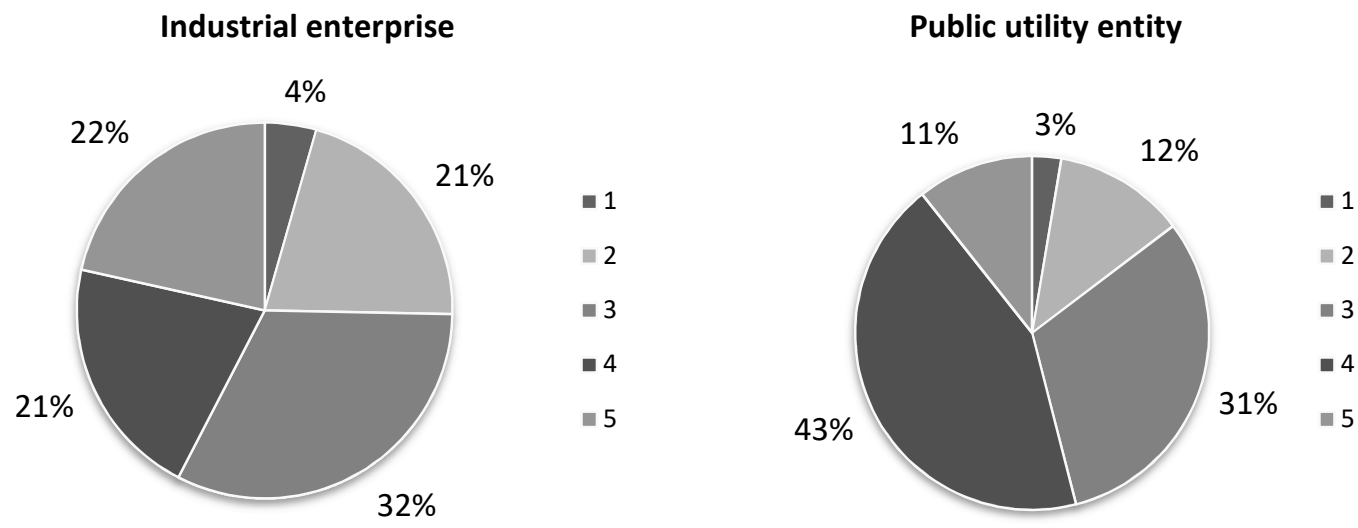

Fig. 6. The distribution of answers to question No. 5.

Designations: 1 - I strongly disagree, 2 - I rather disagree, 3 - I have no opinion, 4 - I agree rather, 5 - I definitely agree.
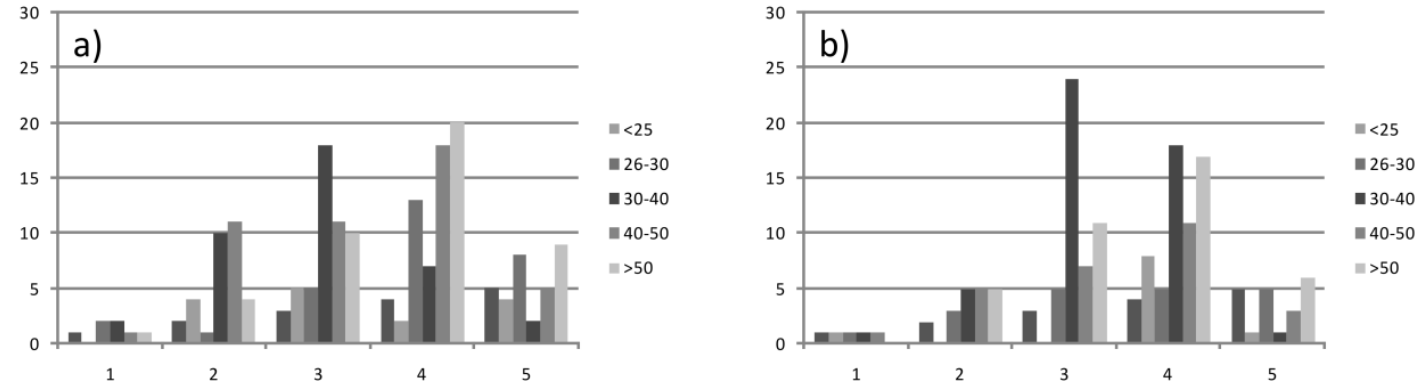

Fig. 7. Distribution of answers to question No. 5. according to the criterion of division: age.

Designations: 1 - I strongly disagree, 2 - I rather disagree, 3 - I have no opinion, 4 - I agree rather, 5 - I definitely agree; a) industrial enterprise, b) public utility entity.

\section{CONCLUSIONS}

The conducted analysis allowed to state that in the surveyed industrial enterprises, employees positively assess selected aspects affecting the development of human capital. Apart from the employees' grades at the level - I have no opinion, it can be concluded that the majority of questions were rated at $4 / 5$, i.e. rather agree and strongly agree.

To the question: The institution in which I am employed takes actions aimed at increasing the level of cooperation between colleagues, this answer was given by $26 \% / 5 \%$ of employees (for comparison in public utility entities it was $30 \% / 11 \%$ of such answers).

In the case of the question: In my workplace, we often exchange information and experiences with our co-workers, $44 \% / 26 \%$ of employees gave such answer (for comparison, in public utility entities it was $53 \% / 30 \%$ of such answers).

On the other hand, the question: My supervisor understands the need for information exchange between employees and takes steps to facilitate this process was answered by $29 \% / 13 \%$ of employees (for comparison, in public utility entities, it was $36 \% / 30 \%$ of such answers).

The question about the degree of computerization of my workplace is sufficient from the point of view of responding efficiency at the level of $4 / 5,26 \% / 13 \%$ of employees (for comparison in public utility utilities it was $49 \% / 21 \%$ of such answers).

Answers to the question: In the institution where I am employed, activities aimed at preservation of acquired knowledge and experience at this level were provided by $21 \% / 22 \%$ of employees (for comparison in public utility entities it was $43 \% / 11 \%$ of such answers). 


\section{REFERENCES}

Bratnicki, M., Strużyna J. and Dyduch W. (2001). Kapitał intelektualny: Odwieczne problemy a nowe propozycje metodologiczne. In: A. Pocztowski, Kapitał intelektualny: dylematy i wyzwania. Nowy Sącz: Wyższa Szkoła Biznesu., pp. 15.

Huselid, M., Jackson, S. and Schuler, R. (1997). Technical and Strategic Human Resources Management Effectiveness as Determinants of Firm Performance. Academy of Management Journal, Vol. 40, No. 1, pp. 171-188.

Imamoglu, SZ., Ince, H. and Turkcan, H. (2017). Linking knowledge sharing, intellectual capital and social capital to innovation performance. European Proceedings of Social and Behavioural Sciences. Vol. 34, pp. 322-331.

Jarugowa, A. and Fijakowska, J. (2002). Rachunkowość i zarządzanie kapitałem intelektualnym. Koncepcje i praktyka. Gdańsk: Ośrodek Doradztwa i Doskonalenia Kadr.

Kasiewicz, S., Rogowski, W. and Kicińska, M. (2006). Kapitał intelektualny. Kraków: Oficyna Ekonomiczna.

Król, H. and Ludwiczyński, A. (2006). Zarządzanie zasobami ludzkimi. Tworzenie kapitału ludzkiego organizacji. Warszawa: PWN.

Prusak, R. (2013) Kształtowanie struktury kapitału intelektualnego przedsiębiorstwa. Częstochowa: Wydawnictwo Politechniki Częstochowskiej.

Prusak, R. (2017). The impact of the level of market competition intensity on enterprises activities in area of intellectual capital. Management-Poland. Vol. 21, Issue 2 pp: 49-61.

Skrzypek, E. (1999). Wpływ zarządzania wiedzą na jakość. Problemy Jakości, 11, pp. 4-5.

Wyrzykowska, B. (2013). Od zasobów ludzkich do kapitału ludzkiego. Częstochowa: Prace Naukowe Akademii im. Jana Długosza w Częstochowie. 